\title{
Treatment of vaginal trichomoniasis with a new anti-protozoal compound ( $\propto$-chloromethyl-2-methyl- 5-nitro-1-imidazole-ethanol)
}

\author{
T. H. LEAN* AND D. VENGADASALAM $†$ \\ From the Department of Obstetrics and Gynaecology, Kandang Kerbau Hospital, Republic of Singapore
}

Ro 7-0207 is a derivative of nitro-imidazole-ethanol, namely $\alpha$-chloromethyl-2-methyl-5-nitro-1-imidazole -ethanol. The structural formula is shown in the Figure.

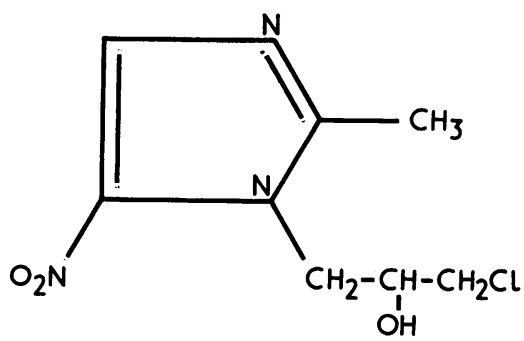

FIGURE Chemical structure of Ro 7-0207

Ro 7-0207 is a light yellow, crystalline substance with a melting range of $74-79^{\circ} \mathrm{C}$. The $\mathrm{pH}$ of a 1 per cent. aqueous solution is about 6.6 . In water its solubility is 2.4 per cent. at $25^{\circ} \mathrm{C}$. In 95 per cent. ethanol its solubility is $>50$ per cent. at $25^{\circ} \mathrm{C}$. Aqueous solutions $(0.5$ per cent.) are relatively stable upon heating at $100^{\circ} \mathrm{C}$. for $1 \mathrm{hr}$. except at $\mathrm{pH}$ values above 7 .

Ro 7-0207 is an effective antiprotozoal agent in experimental infections of rats, hamsters, and mice. It also showed marked activity against Entamoeba histolytica in both intracaecal infection in rats and hepatic infection in hamsters when administered orally, and against hepatic infection when administered subcutaneously. It was also markedly active when administered orally against local and systemic Trichomonas vaginalis and Trichomonas foetus infections in mice. The substance showed moderate activity against $T$. vaginalis when administered by infiltration at the site of infection.

Received for publication July 7, 1972

*Clinical Professor and Senior Consultant tSenior Registrar
For the past decade and more, oral metronidazole has been used as a standard treatment for vaginal trichomoniasis. The present study was designed to assess the efficacy of this new antiprotozoal agent against vaginal trichomoniasis and to compare the results with metronidazole in a randomized doubleblind trial.

\section{Patients and method}

Fifty consecutive women who were found to be infested with Trichomonas vaginalis were included in the trial. Their ages ranged from 20 to 45 years, 90 per cent. being between 20 and 30 years old. Oral contraceptives were used by 45 per cent. and no contraceptives by 40 per cent. Pregnant patients and those suffering from neurological diseases were excluded. Diagnosis was made by darkground microscopical examination of a saline suspension of secretion from the posterior vaginal fornix. Vaginal discharge was the chief complaint in all cases.

Identical capsules were prepared, each containing $200 \mathrm{mg}$. of either Ro 7-0207 or metronidazole or a placebo. Treatment was allocated at random, and the code key was not opened until the trial was completed. All the patients were admitted to the ward for treatment and received one capsule three times a day for 10 days. Four remained in the ward during the 10-day period, and the other 45 were treated as inpatients for the first 5 days and then allowed to continue the treatment as outpatients, and to report back on the 10th day for further investigations. Darkground microscopical examinations of a saline suspension of secretion from the posterior vaginal fornix were made on the 5th and 10th days, and again 3 and 4 weeks after the start of treatment.

Spontaneous complaints attributed to the test drugs were recorded and each patient was then questioned specifically about vaginal discharge, irritation of the vulva, dysuria, frequency of micturition, and malodour.

A complete neurological examination was carried out on admission, as well as haemoglobin, white blood cell count, serum bilirubin, alkaline phosphatase, albuminglobulin ratio, SGPT, blood urea, and microscopical examination and specific gravity of urine; these tests were done before starting treatment and again on the 5 th and 10th days, and after 4 weeks. 


\section{Results}

Twenty patients were treated with Ro 7-0207, twenty with metronidazole, and ten with placebo capsules. There were no defaulters in any of the groups. All who were given Ro 7-0207 were regarded as cured on the evidence of follow-up tests. Seventeen were negative for Trichomonas vaginalis on the 5th day of treatment and two by the 10th day, and all nineteen continued to have negative tests until the 4th week (Table I).

TABLE I

\begin{tabular}{|c|c|c|c|c|}
\hline \multirow{2}{*}{$\begin{array}{l}\text { Treatment } \\
\text { group }\end{array}$} & \multicolumn{4}{|c|}{ No. of negative examinations } \\
\hline & 5th day & 10th day & $3 r d$ week & 4th week \\
\hline $\begin{array}{l}\text { Ro 7-0207 } \\
\text { Metronidazole }\end{array}$ & $\begin{array}{l}18 \\
16\end{array}$ & $\begin{array}{l}20 \\
20\end{array}$ & $\begin{array}{l}20 \\
20\end{array}$ & $\begin{array}{l}19 \\
20\end{array}$ \\
\hline
\end{tabular}

The one remaining patient had a positive test at the end of the 4th week, having been negative on three previous occasions (Table II); this was probably due to re-infection after the 3rd week, as she admitted sexual intercourse during this period. All but one patient in the Ro 7-0207 group stated that the discharge and irritation were much improved after starting the treatment; one continued to complain of discharge and irritation although objectively there was little discharge to see and the signs of vaginitis had decreased. In all these cases the signs improved rapidly and in most there was complete resolution of vaginitis within 1 or 2 weeks, when the original thin, frothy, yellow discharge became thicker and white and rapidly decreased in amount, usually within a few days. In nearly every case, the number of leucocytes seen in the smear showed a marked decrease and the number of epithelial cells increased. These changes often occurred within a few days of starting the treatment and in many cases no more than an occasional pus cell was seen at the end of the treatment.

TABLE II

\begin{tabular}{|c|c|c|c|c|}
\hline \multirow{2}{*}{$\begin{array}{l}\text { Treatment } \\
\text { group }\end{array}$} & \multicolumn{4}{|c|}{ Positive results after starting treatment } \\
\hline & 5th day & 10 th day & 3rd week & 4th week \\
\hline $\begin{array}{l}\text { Ro 7-0207 } \\
\text { Metronidazole }\end{array}$ & $\begin{array}{l}2 \\
4\end{array}$ & - & - & 1 \\
\hline
\end{tabular}

Of the twenty patients treated with metronidazole, sixteen showed negative tests on the 5th day and the remaining four were negative on the 10th day. All were considered to be cured, as the diagnostic tests were negative at the end of the 4th week.

Of the ten cases treated with placebo, all continued to show Trichomonas vaginalis at the end of the period of treatment.

\section{ADVERSE REACTIONS}

No adverse side-effects were found in any of the patients in the entire series. The adverse reactions looked for included dizziness, vertigo, incoordination of movement, disturbed gait or speech, Rombergism, and nystagmus. Blood pressure and pulse were checked regularly. None of the biochemical and haematological values deviated from normal.

\section{Discussion}

For well over 10 years metronidazole has been a main-stay in the management of vaginal trichomoniasis. It has been described as a therapeutic ideal for this condition because of its high cure rate, relative freedom from side-effects, and apparent ease of administration.

The cure rate has been as high as 98 per cent. (Keighley, 1971) in a prison community where the drug was administered under controlled conditions and re-infection was not possible. In other series initial failure rates of less than 10 per cent. have been reported (Rodin, King, Nicol, and Barrow, 1960; Watt and Jennison, 1962; Csonka, 1963; Wisdom and Dunlop, 1965).

Newer compounds have since been made available for the treatment of vaginal trichomoniasis. Evans and Catterall (1971) compared nitrimidazine (Naxogin) with metronidazole; the cure rate was only 68 per cent. with nitrimidazine compared with 89 per cent. with metronidazole.

The present small series reports the use of a new antiprotozoal agent in the treatment of vaginal trichomoniasis. Results with the dosage used appear encouraging, showing the compound to be equally as effective as metronidazole in the same dosage.

It has been constantly stressed that, in the management of trichomoniasis, re-infection must be prevented. The single case of relapse with Ro 7-0207 in this particular series is an example of re-infection after the 3rd week of treatment, and again shows the necessity of investigating the patients' contacts and treating them as well.

\section{Summary}

A new antiprotozoal agent* ( $\alpha$-chloromethyl-2methyl-5-nitro-1-imidazole-ethanol) was compared with metronidazole in a double-blind study for the treatment of vaginal trichomoniasis. Identical capsules, each containing $200 \mathrm{mg}$. of the drug, were given three times a day for 10 days. All the twenty cases (100 per cent.) treated with Ro 7-0207 were cured by one course of treatment. No undesirable side-effects were noted. All the twenty cases treated

*Coded Ro 7-0207-Hoffman La-Roche-Switzerland 
with metronidazole similarly responded to treatment. In the dosage recommended, this derivative of the new compound appears to be as effective as metronidazole when given in the same dosage.

The authors wish to thank Dr. P. A. Buhr, M.D., of the Roche Far East Research Foundation, for randomizing the drug-administration schedule and for supplying all the capsules used in this trial.

\section{References}

CsonkA, G. W. (1963) Brit. F. vener. Dis., 39, 258

Evans, B. A., and CatTerall, R. D. (1971) Brit. med. F., 4, 146

Keighley, E. E. (1971) Ibid., 1, 207

Rodin, P., King, A. J., Nicol, C. S., and BARRow, J. (1960) Brit. F. vener. Dis., 36, 147

Watt., L., and Jennison, R. F. (1962) Brit. med.f., 1, 276

Wisdom, A. R., and Dunlop, E. M. C. (1965) Brit. f. vener. Dis., 41, 90
Traitement de la trichomonase vaginale par un nouvel agent antiprotozoaire $(\alpha-C h l o r o m e ́ t h y 1-2-$ méthyl-5-nitro-1-imidazole-éthanol)

\section{SOMMAIRE}

Lors d'une étude à double insu, un nouvel agent* $(\alpha$-Chlorométhyl-2-méthyl-5-nitro-1-imidazole-éthanol) a été comparé avec le métronidazole dans le traitement de la trichomonase vaginale. Des capsules d'aspect identiques, contenant chacune $250 \mathrm{mg}$ de médicament, furent données trois fois par jour pendant 10 jours. Les 20 cas (100 pour cent) traités avec le Ro 7-0207 furent guéris après une série. Aucun effet fâcheur ne fut noté. Tous les 20 cas traités avec le métronidazole furent guéris de la même manière. A la posologie préconisée, ce dérivé du nouveau composé apparaît être aussi efficace que le métronidazole donné à la même dose.

${ }^{\star}$ Ro 7-0207-Hoffmann La-Roche, Suisse. 